\title{
Does Sustainability Pay? Evidence from the Food Sector
}

\author{
Mehmet Fatih Acar ${ }^{\mathrm{a}}, \mathrm{E}_{\mathrm{Aktas}}^{\mathrm{b}}$, Yavuz Agan ${ }^{\mathrm{c}}$, Michael Bourlakis ${ }^{\mathrm{b}}$ \\ ${ }^{\text {a } P r o j e c t ~ P l a n n i n g ~ E n g i n e e r, ~ H a v a t e k ~ M a k i n a, ~ A O S B, ~ I ̇ z m i r ~, ~ T u r k e y, ~ m e f a c a r 4 @ g m a i l . c o m ~}$ \\ ${ }^{\mathrm{b}}$ Cranfield University, School of Management, College Road, Cranfield, MK43 0AL, UK; \\ emel.aktas@cranfield.ac.uk; m.bourlakis@cranfield.ac.uk
}

${ }^{\mathrm{c}}$ Stafford School of Business, Abraham Baldwin Agricultural College, 2802 Moore Highway, Tifton, GA 31793, USA; yavuz.agan@abac.edu

\begin{abstract}
This research investigates sustainability concepts linking them with social, environmental, and operational activities in the food supply chain. Building on the literature treating social sustainability as an antecedent of environmental sustainability, we present the effects of environmental sustainability on operational performance using constructs that reflect flexibility, quality, and responsiveness. For this purpose, manufacturing companies in Turkish food industry are surveyed and 101 responses are collected. A partial least squares structural equation model (PLS-SEM) is constructed to test the reliability and the validity of the measurement model and the structural model. The results show that social sustainability is positively associated with environmental sustainability. Moreover, environmental sustainability has a positive influence on operational performance measures: flexibility, quality, and responsiveness with effect sizes that range from medium to large. Organizations in the food supply chain should consider not only the economic, but also the social and the environmental aspects of sustainability. To do this, governments could inform manufacturers in the food sector about the importance of sustainability and encourage them with different incentives towards more sustainable operational practices. This work establishes that investing in social and environmental sustainability returns increased operational performance. The limitation of the research is the size of the sample. In the future, the questionnaire can be used to compare results from other countries and other sectors.
\end{abstract}

Keywords: Food Supply Chain, Food SMEs, Sustainability, PLS-SEM 


\section{Introduction}

The integration of social responsibility and environmental consciousness into supply chain operations has led to the emergence of sustainable supply chain management (SSCM) concept. Climate change, environmental pollution, energy prices, and consumer awareness coupled with the demand for transparency amplify the importance of SSCM. The most wellknown definition of sustainable development is offered by the Brundtland Commission (1987): “...development that meets the needs of the present without compromising the ability of future generations to meet their needs." In fact, this macro-economic definition is criticized for not being clear enough to guide organizations and their supply chains in becoming more sustainable (Giddins, 2006, p.942). Therefore, the triple bottom line concept comprising social, environmental, and economic performance is developed (Nikolaou, Tsalis, and Evangelinos, 2019). Since manufacturers purchase many of their components from suppliers, it is impossible for firms to be sustainable without greening their supply chains. Although socially and environmentally responsible companies are increasing in number, there are still many companies, mainly small and medium sized enterprises (SMEs), which need to adopt sustainable operations. Manufacturing companies increasingly consider environmental criteria into their supplier selection processes. For example, Unilever, makes sure its suppliers are aligned with the values of their responsible sourcing policies (https://www.unilever.com/about/suppliers-centre/unilever-supplier-qualification-system/)

In the last years, sustainability is a trending area of research for food supply chain management literature (Luo et al., 2018) due to its implications on sustainable development goals. In fact, food is a common denominator for many sustainable development goals such as SDG1: No Poverty, SDG2: Zero Hunger, SDG3: Good Health and Wellbeing, SDG6: Clean Water and Sanitation, SDG12: Responsible Consumption and Production, SDG14: Life Below Water, and SDG15: Life on Land (Rockström and Sukhdev, 2016). Although the antecedents of food supply chain sustainability have been researched extensively (Zaid et al., 2018), the practices of sustainability and its consequences are relatively novel and open for contributions (Luo et al., 2018). Survey-based and other methods of research are needed to understand and 
improve sustainability in food supply chains. To date, environmental issues have been discussed more in the literature compared to social issues (Ghadimi, Wang, and Lam, 2019). As the literature on sustainable food supply chains (Bourlakis et al., 2014a; Bourlakis et al., 2014b; Validi et al., 2014; Sgarbosso and Russo, 2016) is limited, this study contributes towards closing this gap, by empirically testing the impact of social sustainability and environmental sustainability on firm performance.

Although the environmental sustainability aspects are researched extensively, the social sustainability dimension, defined as stakeholder engagement (ie with suppliers, manufacturers, retailers, or distributors) to avoid human rights abuses, child labor, or irresponsible investment, is generally missing from the sustainable supply chain management literature (Ghadimi, Wang, and Lim, 2009). Our research outlines several elements of sustainability by way of searching for the answers to two questions: (i) does social sustainability affect environmental sustainability and (ii) does environmental sustainability affect the firms' operational performance? Answering these questions, this study contributes to knowledge by clarifying the effect of social sustainability on environmental sustainability, and environmental sustainability on firms' operational performance (i.e., flexibility, quality, and responsiveness). To be convincing to a resource-constrained group of companies such as the SMEs, which are the backbone of the food sector, the relationship between different dimensions of sustainability and operational performance should be established. This is the contribution this paper makes to knowledge by surveying food manufacturing companies on social and environmental sustainability and reveals their connections to operational performance.

On a practical level, the results of this study can help firms understand the importance of sustainability in terms of social, environmental, and operational performance and which factors catalyze the relationship among sustainability dimensions. Because the effect of social sustainability on operational performance of the firm is unclear, by analyzing this relationship through environmental sustainability, this study illuminates the way social responsibility can provide positive impact on operational performance. 


\section{Literature Review}

The research on environmentally sustainable supply chains is proliferating as we face the immediacy of depleting natural resources. Our study is at the interconnection of sustainable supply chain management and food supply chains with focus on food manufacturers, most of which are SMEs. In this section, we review sustainable supply chain literature considering environmental sustainability and put forward our main arguments for the design of the methodology. Moreover, as the food industry is an attractive research area for this topic, we review previous work with primary data collected from food companies. On the other hand, food supply chains are characterized by many SMEs; therefore, we present a synthesis of previous work highlighting the relevance of SMEs for this sector.

\subsection{Sustainable Supply Chain Management}

Sustainability is one of the most crucial aspects of doing business in today's world. Nowadays, climate change and environmental pollution have become one of the main problems requiring immediate response from the academia as well as the industry. Especially, global warming threatens not only the environment but also the humanity. Therefore, the ways of being sustainable are widely discussed and investigated by academics, policy-makers, and politicians. There are many different perspectives for sustainability, but one important concept is the triple bottom line approach (Seuring and Muller, 2008), which implies the "integration and achievement of an organization's social, environmental, and economic goals in the systemic coordination of key inter-organizational business processes for improving the long term economic performance of the individual company and its supply chains" (Carter and Rogers, 2008). Therefore, sustainability can be achieved by simultaneously considering environmental, social, and economic performance (Elkington, 1998).

The increasing consciousness about environment and health puts pressure on companies for their operations. Organizations are expected and have started to take responsibility for the consequences of their production processes. Corporate social responsibility has originated from these type of views (Agan, 2016; Turker, 2009). 
Furthermore, the interaction and integration of corporate social responsibility (CSR) and supply chain management (SCM) has led to the concept of sustainable supply chain management (Reuter et al., 2010; Agan et al., 2016) which implies improving firm performance in all three areas. The main question of SSCM is "What is it that we need to do, not just to survive, but to thrive and not just one year, three years, or five years from now, but in ten years, 20 years and beyond?" (Carter and Easton, 2011).

One of the most important aspects of SSCM is the consideration of environmental damage from production and distribution operations. Disposal, reducing resources, recycling, and using environmental management systems are different ways and levers for dealing with pollution inflicted by companies on the environment. Because disposal is the simplest and an ineffective way of removing material from the supply chain, organizations should find better solutions especially for contaminants. Sustainable or green supply chain management struggles to minimize the disposal volumes (Srivastava, 2007).

Recycling "is simply the reuse of materials from returned products without conserving the product identity" (Kapetanopoulou and Taagaras, 2010). Reduced packaging, more effective redesign for recycling, higher levels of motivation and productivity, shorter lead times, higher quality products, and lower disposal costs are examples of SSCM activities which can be attributed to the application of ISO 14000 standards. An Environmental Management System refers to a holistic approach to environmental issues the company is facing. It is operating in a socially responsible, sustainable, and profitable way beyond responding to legal requirements. An environmental management system imposes the managerial procedures that guide a company in its activities to organize its environmental initiatives (Sayre, 1996; Lefebvre et.al., 2003). Furthermore, Environmental Management System provides a systematic approach to manage the environmental effects of the company (Jorgensen, 2000). Not only companies in heavy or chemical industries, but also each organization, small or large, should prioritize environmental issues in their vision, mission, policy, strategy, values, and actions to protect the nature and to provide more livable habitats for the next generations. 
Firms should ensure that sustainable operations are applied by their suppliers as irresponsible behavior of a supplier may damage the buying firm in terms of deterioration of product quality, adverse publicity, reputational damage, and costly legal obligations (Carter and Jennings 2004, cited by Reuter et al., 2010; Koplin et. al. 2007). Therefore supplier selection and development are crucial decision areas for buyers. Waste levels, transportation of hazardous materials, and carbon emissions are considered as critical aspects for buyers where contracts with suppliers may not be renewed in cases of poor performance. There are three effects of sustainable supplier development for organizations: first, suppliers can quickly respond to expectations of buyers. Second, the image of a buying firm improves, and third, sustainable supplier development affects the performance of a firm positively through higher quality products and security of supply (Reuter et al., 2010).

Carter and Jennings (2002) show that social responsibility criteria, which are determined via in-depth interviews in logistics operations, are related to purchasing, transportation, and warehousing departments. They listed social responsibility activities in logistics such as; purchasing recyclable and reusable packaging and containers, ensuring proper labeling, documentation \& packaging of hazardous materials, reducing packaging material, helping to develop local suppliers, donating gifts received from suppliers, reverse logistics, and proper storage. Maloni and Brown (2006) classify social responsibility in food supply chains as activities related to animal welfare, biotechnology, environment, fair trade, health and safety, and labor and human rights.

SMEs are responsible for 70 percent of all industrial pollution (Hillary, 1995) and manufacturers generally purchase their products from small and midsize suppliers, therefore it is impossible to realize sustainability without sustainable SMEs. However, a recent survey on sustainable supply chain management by Ghadimi, Wang, and Lim (2009) establishes the lack of focus in the research domain on SMEs although their collective ecological and social impacts are overwhelming. 


\subsection{Food SCM}

The importance of food and agricultural sectors is increasing in the last decades. For example, according to Kinsey (2001), 9\% of the US gross domestic product (GDP) was the food and agricultural sector in 2000 and the contribution of agriculture to the GDP is growing. Food market, especially fresh produce, is a dynamic sector (Huang, 2004). For instance, nearly a quarter of all US food expenditures is incurred for fresh agri-foods (Epperson and Estes, 1999). Because of population growth and increasing public awareness of the healthier diets, the production trends in food and agricultural sectors are changing (McLaughlin et al, 2000). Additionally, people may want to consume different food and agricultural products like fruits imported from overseas at any time of the year, especially in developed countries. These reasons increase the complexity of food supply chains (See Aysoy et al., 2015; Atallah et al., 2014; Aubry and Kebir, 2013; Fritz and Schiefer, 2008; Kaditi, 2013; Faisal and Talib, 2016; Sigala, 2007). For example, the winter fresh produce sold in Northern Europe is produced in Turkey, Spain, and other countries (Ahumada and Villalobos, 2008), contributing to CO2 emissions from transportation and increasing water consumption.

Supply chain capabilities of firms affect the efficiency of these sectors, because frequent changes are observed in demand and transportation problems. So, many companies trading in food and agricultural markets attempt to improve their supply chain capabilities. The food supply chains are quite dissimilar to supply chains of other products because the distribution operation should ensure the quality and the safety of the food product as it is transported downstream in the chain until it reaches the consumer (Akkerman et al., 2010). In the food supply chain, temperature is a key factor affecting food quality and safety. Failure to maintain the right temperature along the chain deteriorates the food and increases the risk of harmful bacteria growing such as Salmonella and E. coli.

\subsection{Importance of SMEs}

Many small, medium, and large companies cause environmental pollution by emitting waste in gas, liquid, and solid forms. There are over 2.5 million SMEs in Turkey (TUIK, 2008), which comprise 99.8 percent of all companies in Turkey (Karpak and Topcu, 2010). The 
European Commission defines SMEs as "enterprises which employ fewer than 250 persons and which have an annual turnover not exceeding EUR 50 million, and/or an annual balance sheet total not exceeding EUR 43 million". It is widely accepted that approximately 70 per cent of all industrial pollution is caused by SMEs (Hillary, 1995).

Any manufacturer spends more than 60 per cent of its income on materials and services (Krajewski et. al., 2010). This confirms that SMEs produce a large and usually polluting portion of finished products, such as food trimmings. Therefore, original equipment manufacturers (OEMs) and their suppliers are liable for their direct and indirect contribution to environmental pollution. If companies want to have sustainable operations, they should not load hazardous and/or environmentally polluting operations onto suppliers which could be SMEs. Unfortunately, many focal firms are ignorant or satisfied if the suppliers' operations are legal in their countries where environmental laws are weak. Using small and midsized suppliers that do not have appropriate environmental capabilities should not be a pretext for OEMs to operate as they did in the past.

\subsection{Hypothesis Development}

When it comes to SMEs, personal and ethical values of the founder can affect the environmental policy of their firm (Walker et al., 2008). Moreover, not only top management, but also middle management's support affects environmental management positively (Carter et. al., 1998). In addition, corporate social responsibility (CSR) is an important driver for environmental management. CSR corresponds to the obligations of a firm to the society and specifically its stakeholders (Smith, 2003). Because CSR provides a worthy status for differentiation in highly competitive markets, many firms are emphasizing the environmental sensitivity in their advertisements and public reports. For instance, FTSE100 - the 100 highly capitalized UK companies in London Stock Exchange - provide their environmental reports (Smith, 2003) and we observe that over time, socially and environmentally responsible companies are increasing in number. Hence, we conclude:

H1: There is a positive relationship between social sustainability efforts and environmental sustainability activities. 
Environmental management practices borne out of environmental responsibility have positive effects on a firm's financial, marketing, and operational performance. However, there are few studies that investigate the impact of environmental sustainability on the firm's operational performance (Goyal et al., 2013). Whilst addressing this gap in the literature, we analyze the impact of environmental sustainability on three commonly used indicators of operational performance: flexibility, quality, and responsiveness (Bourlakis et al., 2014a).

Quality is measured by product conservation time, traceability, storage and delivery conditions, and packaging. Sustainability within food supply chains generally means reduction of product waste (i.e. products that must be thrown away because the food is not suitable for consumption) and greenhouse gas emissions due to production and delivery processes (Van der Vorst et al., 2009). Therefore, the final product quality is of utmost importance for food supply chain performance and sustainability. Inadequacies in any of these quality dimensions result in waste of natural resources and energy. Product conservation time refers to the length of time a food product within the chain maintains the desired properties and characteristics before it starts to decay (Bourlakis et al., 2014a). Improper storage and delivery conditions combined with poor packaging shortens the product conservation time and speeds up food deterioration. Consumer confidence in the quality and safety of food products at the end of the food chain is a critical factor for reducing food waste (Vasileiou and Morris, 2006), and hence for reducing consumption of energy and materials in the production process (Bourlakis et al., 2014a). Therefore, companies with environmental responsibility are expected to get involved in practices that reduce or eliminate waste. Van der Vorst et al. (2009) propose an integrated approach where logistics choices (i.e. delivery, storage, and packaging) impact the food quality and sustainability performance of the firm. Hence, we conclude:

H2: Higher engagement in environmental sustainability activities is associated with higher quality performance.

There are three types of flexibility used in our study: 1) delivery flexibility 2) volume flexibility and 3) new product flexibility. Delivery flexibility is a measure of the firm's ability to re-route food products within the supply chain to avoid waste. This is particularly important 
in the later stages of the food chain, as losses incurred here are not only the loss of the product itself, but also the loss (i.e. the waste) of all resources devoted to getting the product so far down the chain (Bourlakis et al., 2014a). Volume flexibility is the firm's ability to produce varying levels of output. Customers can buy just the amount they need and don't generate waste by overpurchasing. New product flexibility is a major advantage that gives companies an edge in the competition. Companies can produce environmentally safe products by changing the product, process, or raw materials. Montabon et al. (2007) also find that environmental management practices are positively related to product and process innovation. Companies with high environmental responsibility are expected to build product flexibility in their business. Hence, we conclude:

H3: Higher engagement in environmental sustainability activities is associated with higher flexibility performance.

The final measure of performance is responsiveness. The difference between flexibility and responsiveness is discussed in the literature. Flexibility is defined as the specific internal mechanisms to improve the responsiveness of the entire organizational system (Bernardes and Hanna, 2009). For example, Holweg (2005) claims that flexibility of the total operation can be expressed as responsiveness; therefore, flexibility often stands for the tools of responding activities. Although all flexible systems do not have enough responsive capabilities, it is expected that companies use their flexibility competence to respond to changes (Matson and McFarlane, 1999). It means that flexibility refers the availability of options, which may be employed to respond to disturbances. Flexibility is a qualification of the organization, whereas responsiveness is a result or benefit of that capability to satisfy changing demand (Bernardes and Hanna, 2009).

Responsiveness is a measure of the firm's accuracy and ability to consistently get the right product in the right place, at the right time. Bourlakis et al. (2014a) propose three measures of responsiveness: the responsiveness in meeting the arranged lead times (i.e. right time), the responsiveness in delivering to the arranged point of sales (i.e. right location), and the responsiveness in delivering the product as ordered (i.e. correct type and quantity). Order 
fulfillment covers a range of activities beginning from the moment the order is placed to the time it is delivered. A perfect order has the traditional 7R: Getting the right product to the right customer, in the right quantity, in the right condition, at the right place, at the right time, and at the right cost (Coyle et al., 2003). Several of these "rights" have been addressed in quality and flexibility measures. The right product, right time, and responsiveness to customer complaints are covered under responsiveness. Responsiveness efforts minimize or eliminate double handling or re-shipments, unnecessary delays, product deterioration (especially for perishable items), inability to plan or schedule in the supply chain (especially for products waiting for other ingredients), expediting, and waste at all levels and shapes. Vachon and Klassen (2008) show positive relationships between environmental collaboration with supply chain partners and quality, flexibility, and responsiveness performance of a manufacturing firm. Supplier development programs provide improvements in quality, delivery, as well as reduction in lead times and supply costs (Modi and Mabert, 2007). Hence we conclude:

H4: Higher engagement in environmental sustainability activities is associated with higher responsiveness performance.

The hypotheses discussed in this research about social sustainability, environmental sustainability, and operational performance (flexibility, quality and responsiveness) are shown in Figure 1.

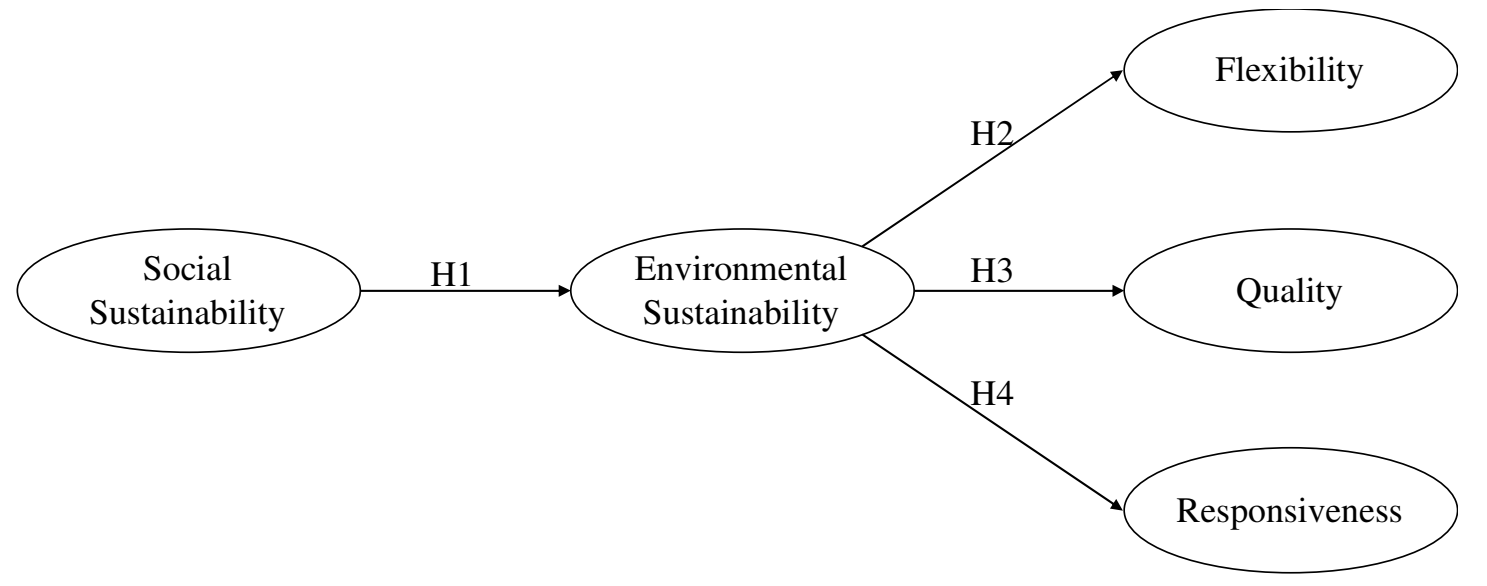

Figure 1 Conceptual Model of Hypothesized Relationships 


\section{Methodology}

To measure social sustainability efforts, environmental sustainability activities, and operational performance dimensions of flexibility, quality, and responsiveness, we used existing and tested measures. Table 1 presents the latent constructs (social sustainability, environmental sustainability, flexibility, quality, and responsiveness) together with their measurement items and the corresponding source papers.

Table 1 Measurement items for criteria

\begin{tabular}{|c|c|}
\hline Constructs and Measurement Items & Literature \\
\hline \multicolumn{2}{|l|}{ Flexibility } \\
\hline $\begin{array}{l}\text { Flexibility in extra volume orders } \\
\text { Flexibility in delivering in extra point of sales } \\
\text { Introducing new products to the market }\end{array}$ & $\begin{array}{l}\text { Aramyan et al. (2007); } \\
\text { Lohman et al. (2004); } \\
\text { and newly developed }\end{array}$ \\
\hline \multicolumn{2}{|l|}{ Quality } \\
\hline $\begin{array}{l}\text { Quality of the firm's product } \\
\text { Product conservation time (Shelf time) } \\
\text { Consistency of traceability system } \\
\text { Storage and delivery conditions } \\
\text { Quality of packaging }\end{array}$ & $\begin{array}{l}\text { Aramyan et al. (2007); } \\
\text { van der Vorst (2005); } \\
\text { Tracey et al. (2005); } \\
\text { Chen \& Paulraj (2004); } \\
\text { Beamon (1999); } \\
\text { Molnar et al. (2010) }\end{array}$ \\
\hline \multicolumn{2}{|l|}{ Responsiveness } \\
\hline $\begin{array}{l}\text { Responsiveness in the arranged lead time } \\
\text { Responsiveness in delivery in terms of arranged point of sales } \\
\text { Responsiveness in delivery in terms of the ordered type of product } \\
\text { Response to customer complaints }\end{array}$ & $\begin{array}{l}\text { Sanchez \& Perez } \\
(2005) ; \\
\text { Chen \& Paulraj (2004); } \\
\text { Bourlakis et al. (2014a); } \\
\text { Molnar et al. (2010) } \\
\end{array}$ \\
\hline \multicolumn{2}{|l|}{ Environment } \\
\hline $\begin{array}{l}\text { Purchasing recyclable and reusable packaging and containers } \\
\text { Ensuring proper labelling or storage documentation } \\
\text { Ensure that our processes and products are environmentally sound } \\
\text { Design of products for recycling and reuse } \\
\text { Try to minimize our energy consumption like water, gasoline etc. }\end{array}$ & $\begin{array}{l}\text { Carter and Jennings } \\
\text { (2002a) and newly } \\
\text { developed }\end{array}$ \\
\hline \multicolumn{2}{|l|}{ Social Responsibility } \\
\hline $\begin{array}{l}\text { Develop our suppliers } \\
\text { Encourage our suppliers to use resource optimally } \\
\text { Try to understand other chain members' interests } \\
\text { Source from environmentally sound suppliers }\end{array}$ & $\begin{array}{l}\text { Carter and Jennings } \\
(2002 b) ; \\
\text { Molnar et al. (2010) and } \\
\text { newly developed }\end{array}$ \\
\hline
\end{tabular}

The exact wordings of the questions are given in the Appendix. 


\subsection{Data collection and descriptive analysis}

After having identified appropriate measures for social sustainability, environmental sustainability, and operational performance constructs, the authors devised a questionnaire survey in line with the literature presented in Table 1. First, the survey was reviewed by the fourth author, who is an established professor who publishes prolifically on food supply chain management using similar methodologies. Then the survey was presented to two experts on supply chain management outside the author team. Once the English version of the survey is concluded, the first and the second author translated the survey into Turkish. Then the survey was reviewed by professors who are native speakers of Turkish and who are experts in supply chain management. Finally, the survey was pilot tested with 10 manufacturing companies before commencing the full data collection. Minor corrections were made to wording throughout this process and the author team deployed the survey at large after this pilot stage.

The author team identified a list of food SMEs from a government website published by the Ministry of Agriculture hosting a directory of agricultural information on companies operating in the food sector (www.tarimrehberi.gov.tr). The next step was to identify the email addresses of the companies listed in this directory. For this purpose, the third author assigned undergraduate students he taught in the Supply Chain Management module the task of identifying the email addresses of food SMEs via an Internet search and sending them the survey link. The reason for including undergraduate students in data collection was to increase the response rate. A total of 895 SMEs received email invitations to participate in the research and 101 of these completed the survey. The response rate is $11 \%$, which is comparable to other surveys done in industry. Two of the responses were entered by non-food companies (a steel manufacturer and a fertilizer / fuel oil retailer); hence their responses were excluded from the sample.

We used the EU's SME definition to determine the SME status of a firm included in the sample (http://ec.europa.eu/growth/smes/business-friendly-environment/sme-definition/). As can be seen in Table 2, companies with a turn-over or a balance sheet total of less than or equal to $€ 2 \mathrm{M}$ and with fewer than 10 employees are considered Micro, companies with a turn- 
over or a balance sheet total of less than or equal to $€ 10 \mathrm{M}$ and with fewer than 50 employees are considered Small, and companies with a turn-over of less than or equal to $€ 50 \mathrm{M}$ or a balance sheet total of less than or equal to $€ 43 \mathrm{M}$ and with fewer than 250 employees are considered Medium sized enterprises. Any company that is above these thresholds is considered a large company. Table 2 presents the number of companies in each category in line with the EU's definition of company size. As can be seen, the number of companies in each size category is comparable except with relatively fewer companies in the micro category.

Table 2 Size and number of employees of firms in the sample

\begin{tabular}{|c|c|c|c|c|c|}
\hline \multirow[b]{2}{*}{ Turnover $(\mathbf{T})$} & \multicolumn{4}{|c|}{ Number of Employees } & \multirow[b]{2}{*}{ Total } \\
\hline & $1-9$ & $10-49$ & $50-249$ & $250+$ & \\
\hline $\mathrm{T} \leq € \mathbf{2 M}$ & 7 & 20 & 3 & & 30 \\
\hline$€ 2 \mathrm{M}<\mathrm{T} \leq € 10 \mathrm{M}$ & 2 & 11 & 13 & & 26 \\
\hline$€ 10 \mathrm{M}<\mathrm{T} \leq € 50 \mathrm{M}$ & 2 & 4 & 8 & 9 & 23 \\
\hline$€ \mathbf{5 0 M}<\mathrm{T}$ & & 2 & 6 & 8 & 16 \\
\hline Not declared & & 4 & & & 4 \\
\hline Total & 12 & 42 & 30 & 17 & 99 \\
\hline
\end{tabular}

\begin{tabular}{|l|l|}
\hline Firm Size & Total \\
\hline Micro & $\mathbf{7}$ \\
\hline Small & $\mathbf{3 7}$ \\
Medium & $\mathbf{3 0}$ \\
\hline Large & $\mathbf{2 5}$ \\
\hline
\end{tabular}

Table 2 shows the two factors, the number of employees and the turnover of companies to decide on the SME status of the food companies. Where the respondents did not declare their turnover, we used the number of employees to identify their category.

The respondents were senior managers (61), owners (31), engineers (2) and others such as; accounting, sales, logistics managers, procurement and not declared (5). It is not surprising that since the majority of the participants of the survey were from SMEs in this research, the respondents were mostly owners and senior managers.

We had more participants from SMEs than large companies; but this is not surprising as the food supply chains have many more SMEs than large companies. We divided the data according to company size (large versus SME) and tested any differences among the responses and found no statistically significant difference in results between large companies and SMEs.

Error! Reference source not found. presents the company characteristics of the food manufacturers in the sample in terms of the operating area. 
Table 3 Food sub-sectors represented in the sample

\begin{tabular}{|l|l|l|}
\hline Food Sector & Frequency & Percentage \\
\hline Biscuits and Confectionary & 15 & $15 \%$ \\
\hline Catering & 14 & $14 \%$ \\
\hline Bakery Products & 12 & $12 \%$ \\
\hline Dairy Products & 11 & $11 \%$ \\
\hline Meat Products & 9 & $9 \%$ \\
\hline Cereals and Pulses & 8 & $8 \%$ \\
\hline Beverages & 7 & $7 \%$ \\
\hline Fruits and Vegetables & 5 & $5 \%$ \\
\hline Spices, Nuts, and Medicinal Herbs & 5 & $5 \%$ \\
\hline Processed Food Products & 4 & $4 \%$ \\
\hline Food Additives & 3 & $3 \%$ \\
\hline Frozen and Preserved Food Products & 3 & $3 \%$ \\
\hline Oils & 3 & $3 \%$ \\
\hline Total & 99 & $100 \%$ \\
\hline
\end{tabular}

Our sample is collected from food companies. Despite the small sample size, the data are valuable as they represent views of the food manufacturers, majority of which are SMES. 100 observations can be sufficient to achieve acceptable measurement and structural models (Reinartz, Haenlein, and Henseler, 2009) and we are just below the recommended threshold.

\section{Findings}

We used the SmartPLS 3 (Ringle et al., 2014) in our exploratory context of examining the social and the environmental sustainability practices in relation to firm operational performance reflected in flexibility, quality, and responsiveness.

We assume that all latent variables are measured by reflective indicators. This necessitates a strong mutual association between the indicators; in other words, they should be highly correlated. Since the reflective measurement assumes that the latent variable is the cause of reflective indicators, they should also load higher on their latent variables than other constructs. We employed several checks on the measurement model such as common method variance, indicator reliability, internal consistency reliability, convergent validity, and discriminant validity. Once we concluded that the measurement model was satisfactory, i.e. it 
measured the constructs we intended to measure, we investigated the structural model in terms of predictive relevance and assessment of structural relations.

Common method variance. It is necessary to check the common-method variance to ensure the data had no issues with regards to response bias since we had a single respondent from each food manufacturer (Prajogo and McDermott, 2014). To assess common method variance, we followed the one-factor test as described in Podsakoff et al. (2003). If there is a substantial amount of common method variance, then a single factor should emerge from the analysis accounting for the majority of the variance. We subjected the dataset to principal component factor analysis in SPSS 22.0.0.1. The varimax rotation suggested a five-factor structure explaining $63 \%$ of the variance with the first factor extracted explaining only $17.5 \%$ of the variance in the data set. When we also force only one factor to be extracted from the data, it was able to explain only $36 \%$ of the variance; therefore, we concluded that the common method variance was unlikely to pose a significant problem in this study.

Indicator reliability. In the case of reflectively measured constructs, loadings above 0.70 indicate that the construct explains more than $50 \%$ of the indicator's variance (Sarstedt et al., 2014). Table 4 presents the loadings of indicators on their corresponding constructs.

Table 4 Outer Loadings of Indicators on Their Respective Constructs

\begin{tabular}{|l|c|l|l|l|l|}
\hline & $\begin{array}{l}\text { Environmental } \\
\text { Sustainability }\end{array}$ & Flexibility & Quality & Responsiveness & $\begin{array}{l}\text { Social } \\
\text { Sustainability }\end{array}$ \\
\hline Env1 & 0.639 & & & & \\
\hline Env2 & 0.824 & & & & \\
\hline Env3 & 0.791 & & & & \\
\hline Env4 & 0.747 & & & & \\
\hline Flex1 & & 0.785 & & & \\
\hline Flex2 & & 0.879 & & & \\
\hline Flex3 & & 0.798 & & & \\
\hline Qual1 & & & 0.742 & & \\
\hline Qual2 & & & 0.696 & & \\
\hline Qual3 & & & 0.806 & & \\
\hline Qual4 & & & 0.744 & & \\
\hline Qual5 & & & 0.820 & & \\
\hline Qual6 & & & 0.834 & & \\
\hline Res1 & & & & 0.879 & \\
\hline
\end{tabular}




\begin{tabular}{|l|l|l|l|l|l|}
\hline Res2 & & & & 0.750 & \\
\hline Res3 & & & & 0.855 & \\
\hline Soc1 & & & & 0.712 \\
\hline Soc2 & & & & & 0.836 \\
\hline Soc3 & & & & & 0.780 \\
\hline Soc4 & & & & 0.730 \\
\hline
\end{tabular}

Env: Environment; Flex: Flexibility; Qual: Quality; Res: Responsiveness; Soc: Social

All of the 20 indicators except Env1 and Qual2 in Table 4 have loadings above 0.70. Hence, we conclude that the indicators in the measurement model show satisfactory reliability levels.

Internal consistency reliability. Internal consistency reliability is evaluated using Jöreskog's (1971) composite reliability where values above 0.70 are considered "satisfactory to good" (Hair et al., 2013). The measurement model has composite reliability values of 0.839 and higher, providing evidence for concluding that the construct measures have internal consistency reliability (Error! Reference source not found.).

Convergent validity. Convergent validity measures the extent to which a construct converges in its indicators by explaining the items' variance. It is assessed by the average variance extracted (AVE) for all items associated with each construct. The AVE value is the mean of squared loadings for all indicators associated with a construct and it should be 0.50 or higher, meaning that the construct explains more than $50 \%$ of the variance of its indicators. As can be seen in Error! Reference source not found. (column titled Average Variance Extracted), all AVE values are higher than the critical threshold value of 0.50 , providing support for us to conclude that the measures have convergent validity.

Table 5 Composite Reliability and Average Variance Extracted

\begin{tabular}{|l|c|c|c|}
\hline Construct & $\begin{array}{l}\text { Cronbach's } \\
\text { Alpha }\end{array}$ & $\begin{array}{l}\text { Composite } \\
\text { Reliability }\end{array}$ & $\begin{array}{l}\text { Average Variance } \\
\text { Extracted }\end{array}$ \\
\hline Environmental Sustainability & 0.744 & 0.839 & 0.568 \\
\hline Flexibility & 0.765 & 0.861 & 0.675 \\
\hline Quality & 0.867 & 0.900 & 0.601 \\
\hline Responsiveness & 0.772 & 0.868 & 0.688 \\
\hline Social Sustainability & 0.766 & 0.850 & 0.587 \\
\hline
\end{tabular}


Discriminant validity. After establishing the reliability and the convergent validity of the constructs, we assessed their discriminant validity, which determines the extent to which a construct is empirically distinct from other constructs. The most conservative criterion that evaluates discriminant validity, the Fornell and Larcker (1981) criterion, compares the square root of the AVE of each construct to the inter-construct correlation of that construct with all other constructs. We show in Table 6, the square root of the AVE of each construct on the diagonal exceeds the inter-correlations of the construct with the other constructs, in support of discriminant validity (Wetzels et al, 2009).

Table 6 Discriminant Validity*

\begin{tabular}{|l|l|l|l|l|l|}
\hline & 1 Env Sus & 2 Flex & 3 Qual & 4 Res & 5 Soc Sus \\
\hline 1 Environmental Sustainability & 0.754 & & & & \\
\hline 2 Flexibility & 0.459 & 0.821 & & & \\
\hline 3 Quality & 0.590 & 0.577 & 0.775 & & \\
\hline 4 Responsiveness & 0.580 & 0.583 & 0.680 & 0.830 & \\
\hline 5 Social Sustainability & 0.644 & 0.451 & 0.551 & 0.450 & 0.766 \\
\hline
\end{tabular}

* Square root of AVE on diagonal.

Once the measurement model checks are complete and satisfactory, having met the empirical thresholds proposed in the literature, we progressed to evaluate the structural model. For this purpose, we check predictive relevance and significance of path coefficients.

Predictive relevance $\left(\boldsymbol{R}^{2}\right.$ and $\left.\boldsymbol{Q}^{2}\right)$. Coefficient of determination $\left(R^{2}\right)$, cross-validated redundancy $\left(Q^{2}\right)$, and the path coefficients are checked to establish predictive relevance. Figure 2 shows the predictive power of endogenous constructs with $R^{2}$ values reported inside circles that represent constructs. Using the cutoffs of .67 for substantial, .33 for moderate and .19 for weak explanatory power (Eksoz et al., 2018) for the $R^{2}$ we conclude that the $R^{2}$ values for environmental sustainability $\left(R^{2}=0.415\right)$, responsiveness $\left(R^{2}=0.337\right)$, quality $\left(R^{2}=0.348\right)$, and flexibility $\left(R^{2}=0.233\right)$ are moderate and satisfactory 
considering the exploratory nature of the study.

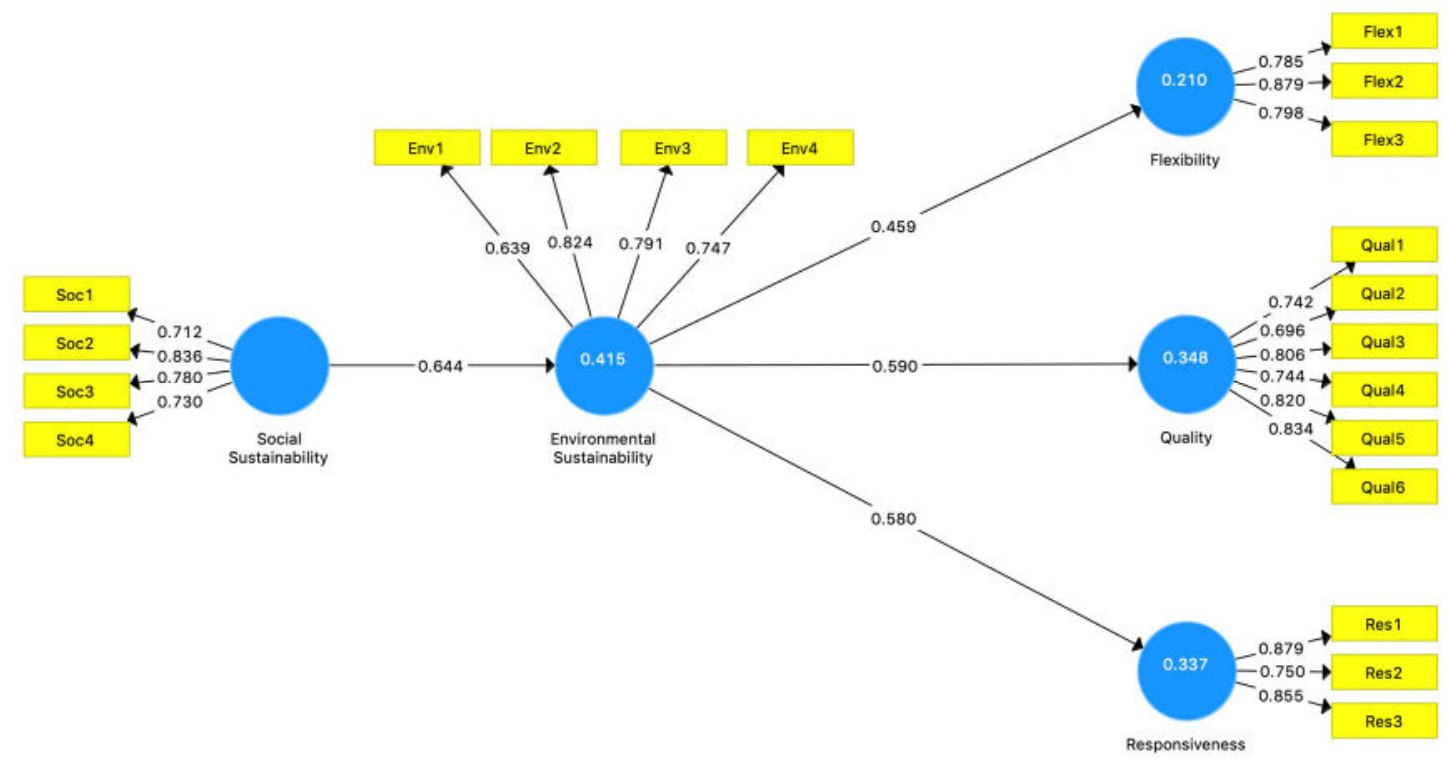

Figure 2 Theoretical Model and Analysis Results

A $Q^{2}$ value larger than zero for an endogenous latent variable indicates the PLS path model has predictive relevance for this construct. This $Q^{2}$ value is obtained by the blindfolding procedure which deletes data points from the sample and provides a prognosis for their original values (Hair et al., 2017). The blindfolding procedure is applied only to endogenous constructs that have a reflective measurement model specification. The $Q^{2}$ values greater than 9 suggest the model has predictive relevance for the endogenous construct in question, whereas $Q^{2}$ values equal to or less than zero indicate a lack of predictive relevance. The $Q^{2}$ values for the constructs in our structural model are as follows. Environmental Sustainability: 0.206; Flexibility: 0.110; Quality: 0.166; Responsiveness: 0.192. Hence, we conclude that our structural model has predictive relevance.

Significance of Structural Relations. A final step is to establish the significance of the path coefficients associated with the hypotheses developed in the literature section. For this purpose, we conducted PLS path modelling and then performed bootstrapping (5000 samples) on the results. We report the $95 \%$ confidence intervals (C.I.) for the path coefficients along with the statistical significance ( $p$-value) in Table 7. As can be observed from Table 7, all 
path coefficients are significantly different from zero and confidence intervals suggest moderate to strong effect.

Table 7 Significance and relevance of path coefficients

\begin{tabular}{|l|l|l|c|}
\hline \multicolumn{1}{|c|}{ Hypothesis } & Path Coefficient & 95\% C.I. & $\boldsymbol{p}$ \\
\hline H1: Soc Sus $\rightarrow$ Env Sus & 0.644 & {$[0.494,0.784]$} & 0.000 \\
\hline H2: Env Sus $\rightarrow$ Flexibility & 0.459 & {$[0.263,0.661]$} & 0.000 \\
\hline H3: Env Sus $\rightarrow$ Quality & 0.590 & {$[0.366,0.768]$} & 0.000 \\
\hline H4: Env Sust $\rightarrow$ Responsiveness & 0.580 & {$[0.330,0.751]$} & 0.000 \\
\hline
\end{tabular}

The results in Table 7 highlight the important role of social sustainability on environmental sustainability with significant and strong path coefficient (0.644). Table 7 also shows the role of environmental sustainability in achieving flexibility, quality, and responsiveness with significant and strong path coefficients $(0.459,0.590$, and 0.580 respectively). The empirical data strongly supports the four hypothesized relationships.

\section{Discussion}

The positive relationship between environmental management and the three measures of performance is an indication of how ethical and good management is the source of sound decisions. As researchers stated many times, environmental decisions are also effective decisions for business. For example, using trucks with more efficient engines or burning less oil, energy, or electricity will not only produce less greenhouse gases but also will reduce costs. However, finding a positive relationship between environmental sustainability and flexibility, quality, and responsiveness is refreshing and thought-provoking. These relationships are not well investigated and understood. In that sense, this paper is an important contribution to understanding the results of social and environmental sustainability on the diverse aspects of operational performance.

While environmental performance of the product can be easily associated with quality, the relationship between sustainability and flexibility and responsiveness may not. Being flexible in terms of volume, delivery, and new products and responding to customer needs, wants, and complaints will reduce waste and increase efficiencies along the supply chain. 
Eventually energy, material, and burden on the environment (i.e. production and transportation outcomes) will not be wasted. The products will arrive where they are needed and in the quantities and specifications they are required. This will prevent long shelf lives, waste, spoilage, and poor quality. For instance, only the bread wasted in Turkey in 2012 amounts to $\$ 242$ million, and the amount of food wasted annually is about $\$ 1$ trillion in the world (http://www.ekmekisrafetme.com, website in Turkish, can be read via Google Chrome Translate). In developing countries $40 \%$ of the food is spoiled before it arrives to the consumer due to poor transportation and the lack of warehouses.

The research on the relationship between sustainability and operational performance have produced mixed results causing both researchers and practitioners to be suspicious of the consequences of investing in sustainability. Although this study alone will not be sufficient to clear these suspicions, it is a strong contribution in the right direction. Another valuable contribution of our study is that it connects sustainability to competitive priorities and therefore strategy. Sustainability should have real and significant effect on strategy formulation and execution. How companies change their strategy in the face of changing customer attitudes, choices, and trends has always been a topic of interest for researchers. As a special case, when concerns for climate change is rising accompanied by trends like eating healthy, consuming organic food and rejecting GMO raises sustainability as a competitive priority. It is worth analyzing how food companies will transition their strategies in the coming decades.

While sustainability can be achieved by considering environmental, social, and economic performance together, how exactly these will interact and impact each other is not clear. Our study proposes one such model where social sustainability impacts environmental sustainability and environmental sustainability is positively associated with the three aspects of operational performance. However, the relationship can be complex. For example, due to life style changes there are more single people and smaller families. Since they demand smaller quantities, there will be more packaging requirements and hence higher amounts of disposal. While giving customers what they want will increase economic performance, it will reduce environmental performance. On the other hand, offering big quantities that one person or a 
small family cannot consume before the food expires will generate waste (Aktas et al., 2018). Therefore, alternative conceptualizations can be proposed and tested in the future. Moreover, governments should inform food companies, especially SMEs, about the importance of sustainability and encourage them with different incentives such as low tax rates and investment credits.

An obvious implication of our study for practitioners is to emphasize and formulize social sustainability in their organizations. This should start with a good understanding and conceptualizing corporate social responsibility, engraving it in the mission, vision, and plans of the corporation and making it visible to employees at all levels. CSR is eventually based on the roots of understanding morality and ethics by founders and top management of organizations. The study by Turker (2009) would be a good start to understanding and formulating CSR activities in companies.

Food sector can be a major burden for the environment from the growth of the produce (e.g. usage of chemicals, pesticides, herbicides, deforestation etc.), to production (e.g. waste, energy consumption), to delivery (e.g. emissions, excessive packaging) and to disposal after consumption. Companies involved in the supply chain should take part in the reduction of pollution, emissions, and the damage to environment. Eventually solutions require more effective and efficient production and delivery processes throughout the supply chain. In turn, these processes will make firms more flexible, responsive, and high-quality performers.

Managers are recommended to establish visible and quantifiable links between sustainability and operational performance to strengthen the relationship or to avoid a gap in between. Sustainability should be tied to incentives, bonuses, and performance evaluations so that the operational and other performance metrics are strongly associated with it. Otherwise employees may not be convinced with the intention and seriousness of the firms' claims.

\section{Conclusion}

This paper researched sustainability in terms of social, environmental, and operational activities for the food supply chain. In the proposed model, social sustainability is treated as an 
antecedent of environmental sustainability. In addition to this, the impact of environmental sustainability on flexibility, quality, and responsiveness was studied. One of the theoretical implications of this work is to build and test measures for social sustainability. Moreover, we quantitatively established the positive link from social sustainability to environmental sustainability. Although the trend in sustainable supply chain management research focused heavily on environmental sustainability, our work contributes to the existing body of literature by explicitly inquiring the impact of social sustainability on operational performance through environmental sustainability.

Practically, our results shall encourage food companies not only to invest in environmental sustainability but also social sustainability. As the research and practice of sustainable supply chain management progresses, the inquiries we made in our survey will become standard operating practices and will have implications for other companies down on the supply chain, such as companies in the hospitality sector that are the clients of the food manufacturers we surveyed in this paper. Until then, we show the relevance and practicality of considering social and environmental sustainability practices to improving operational performance. In sum, investing in social and environmental sustainability does not detract from flexibility, responsiveness, and quality.

Responses to the designed questionnaire were collected from Turkish food manufacturers. A partial least square structural equation model (PLS-SEM) was used to analyze the reliability and the validity of the measurement and the structural model. According to the results, social sustainability is positively related to environmental sustainability and the environmental sustainability has positive effects on all of the operational performance criteria: flexibility, quality, and responsiveness. Therefore, food SMEs should consider not only the operational performance, but also the social and the environmental issues for sustainability.

One of the limitations of the research is the sample size. More data would enable a more complex model where all the sub constructs of the compound performance measures can be directly related to environmental sustainability to test the individual performance link and 
compare relative strengths. Because the study is conducted in Turkey, findings may not easily be generalized to other countries.

Due to culture (e.g. eating patterns), climate, size of the country, and other variables, future studies conducted in other countries can find differences in findings. Another opportunity for future studies is to include market and financial performance metrics in the model and to search the relationship between operational and other performance measures. While we offer a conceptual model of relationships among factors, we still don't know how exactly the decisionmaking process works when companies face sustainability issues. Future studies should consider the mechanics of the decision-making process and how companies balance sustainability and economic concerns. The positive relationships between social and environmental sustainability and operational performance should encourage firms to take bold decisions on sustainability issues.

\section{References}

Agan, Y., Kuzey, C., Acar, M. F., \& Açıkgöz, A. (2016). The relationships between corporate social responsibility, environmental supplier development, and firm performance. Journal of Cleaner Production, 112, 1872-1881.

Agan, Y., Acar, M. F., \& Borodin, A. (2013). Drivers of environmental processes and their impact on performance: a study of Turkish SMEs. Journal of Cleaner Production, 51, 2333.

Ahumada O., Villalobos J.R., 2009. Application of planning models in the agri-food supply chain: A review. European Journal of Operational Research 195 (2009) 1-20.

Akkerman, R., Farahani, P., \& Grunow, M. (2010). Quality, safety and sustainability in food distribution: a review of quantitative operations management approaches and challenges. Or Spectrum, 32(4), 863-904.

Aktas, E., Sahin, H., Topaloglu, Z., Oledinma, A., Huda, A. K. S., Irani, Z., ... \& Kamrava, M. (2018). A consumer behavioural approach to food waste. Journal of Enterprise Information Management, 31(5), 658-673. 
Ali, S. S., Madaan, J., Chan, F. T. S. and Kannan, S. (2013), "Inventory management of perishable products: A time decay linked logistic approach", International Journal of Production Research, vol. 51, no. 13, pp. 3864-3879.

Amorim, P., Belo-Filho, M. A. F., Toledo, F. M. B., Almeder, C. and Almada-Lobo, B. (2013), "Lot sizing versus batching in the production and distribution planning of perishable goods", International Journal of Production Economics, vol. 146, no. 1, pp. 208-218.

Aramyan, L.H., van Kooten, O., van der Vorst, J.G., Oude Lansink, A.G., (2007). Performance measurement in agri-food supply chains: a case study. Supply Chain Manag.: Int. J. 12 (4), 304-315.

Atallah, S. S., Gómez, M. I., \& Björkman, T. (2014). Localization effects for a fresh vegetable product supply chain: Broccoli in the eastern United States. Food Policy, 49, 151159.

Aubry, C., \& Kebir, L. (2013). Shortening food supply chains: A means for maintaining agriculture close to urban areas? The case of the French metropolitan area of Paris. Food Policy, 41, 85-93.

Aysoy, C., Kirli, D. H., \& Tumen, S. (2015). How does a shorter supply chain affect pricing of fresh food? Evidence from a natural experiment. Food Policy, 57, 104-113.

Beamon, B. M. (1999). Measuring supply chain performance. International journal of operations \& production management, 19(3), 275-292.

Bernardes, E. S., \& Hanna, M. D. (2009). A theoretical review of flexibility, agility and responsiveness in the operations management literature: Toward a conceptual definition of customer responsiveness. International Journal of Operations \& Production Management, 29(1), 30-53.

Bottani, E., Ferretti, G., Montanari, R. and Rinaldi, M. (2014), "Analysis and optimisation of inventory management policies for perishable food products: A simulation study", International Journal of Simulation and Process Modelling, vol. 9, no. 1-2, pp. 16-32. 
Bourlakis, M., Maglaras, G., Aktas, E., Gallear, D., \& Fotopoulos, C. (2014a). Firm size and sustainable performance in food supply chains: Insights from Greek SMEs. International Journal of Production Economics, 152, 112-130.

Bourlakis, M., Maglaras, G., Gallear, D., \& Fotopoulos, C. (2014b). Examining sustainability performance in the supply chain: The case of the Greek dairy sector. Industrial Marketing Management, 43(1), 56-66.

Brundtland Report, 1987. Our Common Future. Development and International Cooperation: Environment. Technical report. United Nations Environment Programme (UNEP). Online at: http://www.worldfuturecouncil.org/fileadmin/user_upload/Maja/Future_Justice_Library/1987 -brundtland_pp_1-17.pdf, accessed 08.25.2013.

Carter, C. R., \& Jennings, M. M. (2002a). Logistics social responsibility: an integrative framework. Journal of business logistics, 23(1), 145-180.

Carter, C. R., \& Jennings, M. M. (2002b). Social responsibility and supply chain relationships. Transportation Research Part E: Logistics and Transportation Review, 38(1), 3752.

Carter, C. R., \& Jennings, M. M. (2004). The role of purchasing in corporate social responsibility: a structural equation analysis. Journal of business Logistics, 25(1), 145-186.

Carter, C. R., \& Liane Easton, P. (2011). Sustainable supply chain management: evolution and future directions. International journal of physical distribution \& logistics management, 41(1), 46-62.

Carter, C.R. and Rogers, D.S. (2008), "A framework of sustainable supply chain management: moving toward new theory", International Journal of Physical Distribution \& Logistics Management, Vol. 38 No. 5, pp. 360-87.

Carter, C.R., Ellram, L.M., Ready, K., (1998). Environmental purchasing: benchmarking our German counterparts. International Journal of Purchasing and Materials Management 34 (4), 28-38. 
Chen, I. J., Paulraj, A., \& Lado, A. A. (2004). Strategic purchasing, supply management, and firm performance. Journal of operations management, 22(5), 505-523.

Coyle, J. J., Bardi, E. J., \& Langley, C. J. Jnr. (2003). The management of business logistics: A supply chain perspective.

Eksoz, C., Mansouri, S. A., Bourlakis, M., \& Önkal, D. (2018). Judgmental adjustments through supply integration for strategic partnerships in food chains. Omega. Forthcoming.

Elkington, J. (1998), Cannibals with Forks: The Triple Bottom Line of the 21st Century, New Society, Stoney Creek, CT.

Epperson, J.E., Estes, E.A., (1999). Fruit and vegetable supply-chain management, innovations, and competitiveness: Cooperative Regional Research Project S-222. Journal of Food Distribution 30, 38-43.

Faisal, M. N., \& Talib, F. (2016). Implementing traceability in Indian food-supply chains: An interpretive structural modeling approach. Journal of Foodservice Business Research, 19(2), 171-196.

Fornell, C., \& Larcker, D. F. (1981). Structural equation models with unobservable variables and measurement error: Algebra and statistics. Journal of marketing research, 382388.

Fritz, M., \& Schiefer, G. (2008). Food chain management for sustainable food system development: a European research agenda. Agribusiness, 24(4), 440-452.

Giddens, A. (2006). Sociology. Polity Press. Cambridge.

Goyal, P., Zillur Rahman, and A. A. Kazmi, (2003). Corporate sustainability performance and firm performance research, Management Decision, Vol 51, No.2, 361-379.

Ghadimi, P., Wang, C., Lim, M.K. (2019) Sustainable supply chain modeling and analysis: Past debate, present problems and future challenges. Resources, Conservation and Recycling, 140, pp. 72-84.

Hair, J. F., Ringle, C. M., \& Sarstedt, M. (2013). Editorial-partial least squares structural equation modeling: Rigorous applications, better results and higher acceptance. Long Range Planning, 46(1-2), 1-12. 
Hair Jr F., J., Sarstedt, M., Hopkins, L., \& G. Kuppelwieser, V. (2014). Partial least squares structural equation modeling (PLS-SEM) An emerging tool in business research. European Business Review, 26(2), 106-121.

Hillary, R.,(1995). Small firms and the environment-a groundwork status report. Birmingham: Groundwork.

Holweg, M. (2005). The three dimensions of responsiveness. International Journal of Operations \& Production Management, 25(7), 603-622.

http://ec.europa.eu/growth/smes/business-friendly-environment/smedefinition/index_en.htm, accessed 11.11.2016

Huang, Sophia W., (2004). Global Trade Patterns in Fruits and Vegetables, United States Department of Agriculture, Agriculture and Trade Report No. WRS-04-06.

Jorgensen, S.A., (2000). Systems approach to the environmental analysis of pollution minimization, Lewis Publisher.

Jöreskog, K. G. (1971). Statistical analysis of sets of congeneric tests. Psychometrika, 36(2), 109-133.

Kaditi, E. A. (2013). Market dynamics in food supply chains: The impact of globalization and consolidation on firms' market power. Agribusiness, 29(4), 410-425.

Kapetanopoulou P., Tagaras G., (2011). Drivers and obstacles of product recovery activities in the Greek industry International Journal of Operations \& Production Management 31(2), 148-166.

Karpak, B., \& Topcu, I., (2010). Small medium manufacturing enterprises in Turkey: an analytic network process framework for prioritizing factors affecting success. International Journal of Production Economics 125 (1), 60-70.

Kinsey, J.D., (2001). The new food economy: Consumers, farms, pharms and science. American Journal of Agricultural Economics 83 (5), 1113-1130.

Koplin, J., Seuring, S., \& Mesterharm, M. (2007). Incorporating sustainability into supply management in the automotive industry-the case of the Volkswagen AG. Journal of Cleaner Production, 15(11), 1053-1062. 
Krajewski, L. J., Ritzman P. L., Malhotra M. K., (2010). Operations Management, Processes and Supply Chains. Ninth Edition, Pearson.

Lefebvre E., Lefebvre L.A., Talbot S., (2003). Determinants and impacts of environmental performance in SMEs R\&D Management 33(3), 263-283.

Lohman, C., Fortuin, L., Vouters, M., (2004). Designing a performance measurement system: a case study. Eur. J. Oper. Res. 156 (2), 267-286

Luo, J., Ji, C., Qiu, C., \& Jia, F. (2018). Agri-food supply chain management: Bibliometric and content analyses. Sustainability, 10(5), 1573.

Maloni, M. J., \& Brown, M. E. (2006). Corporate social responsibility in the supply chain: an application in the food industry. Journal of business ethics,68(1), 35-52.

Martínez Sánchez, A., \& Pérez Pérez, M. (2005). Supply chain flexibility and firm performance: a conceptual model and empirical study in the automotive industry. International Journal of Operations \& Production Management, 25(7), 681-700.

Matson, J. B., \& McFarlane, D. C. (1999). Assessing the responsiveness of existing production operations. International Journal of Operations \& Production Management, 19(8), 765-784.

McLaughlin, E.W., Green, G.M., Park, K., (1999). Changing Distribution Patterns in the US Fresh Produce Industry: Mid/Late-70s to Mid/ Late-90s, Department of Agricultural, Resource, and Managerial Economics, Cornell University, Ithaca, NY 14853, June.

Modi, S.B., Mabert, V.A., (2007). Supplier development: improving supplier performance through knowledge transfer. Journal of Operations Management, 25 (1), 42-64.

Molnár, A., Gellynck, X., Vanhonacker, F., Gagalyuk, T., \& Verbeke, W. (2011). Do chain goals match consumer perceptions? The case of the traditional food sector in selected European Union countries. Agribusiness, 27(2), 221-243.

Montabon, F, Robert Sroufe, Ram Narasimhan, (2007). An examination of corporate reporting, environmental management practices and firm performance, Journal of Operations Management, 2007, vol 25, 998-1014. 
Nikolaou, I. E., Tsalis, T. A., \& Evangelinos, K. I. (2019). A framework to measure corporate sustainability performance: A strong sustainability-based view of firm. Sustainable Production and Consumption. 18, 1-18.

Podsakoff, P. M., MacKenzie, S. B., Lee, J. Y., \& Podsakoff, N. P. (2003). Common method biases in behavioral research: a critical review of the literature and recommended remedies. Journal of applied psychology, 88(5), 879.

Prajogo, D., \& McDermott, C. M. (2014). Antecedents of service innovation in SMEs: comparing the effects of external and internal factors. Journal of Small Business Management, 52(3), 521-540.

Reinartz, W., Haenlein, M., \& Henseler, J. (2009). An empirical comparison of the efficacy of covariance-based and variance-based SEM. International Journal of research in Marketing, 26(4), 332-344.

Reuter, C., Foerstl, K. A. I., Hartmann, E. V. I., \& Blome, C. (2010). Sustainable global supplier management: the role of dynamic capabilities in achieving competitive advantage. Journal of Supply Chain Management, 46(2), 45-63.

Ringle, C. M., Silva, D. D., \& Bido, D. (2014). Structural equation modeling with the SmartPLS. REMark: Revista Brasileira de Marketing, 13(2).

Rockström, J. \& Sukhdev, P. (2016) How Food Connects All the SDGs. Presentation made at the Stockholm Food Forum, EAT. https://www.stockholmresilience.org/research/research-news/2016-06-14-how-food-connectsall-the-sdgs.html Date Accessed: 31 October 2018.

Sarstedt, M., Ringle, C. M., Smith, D., Reams, R., \& Hair, J. F. (2014). Partial least squares structural equation modeling (PLS-SEM): A useful tool for family business researchers. Journal of Family Business Strategy, 5(1), 105-115.

Sayre, D., (1996). Inside ISO 14000: The Competitive Advantage of Environmental Management. Delray Beach FL: St.-Lucie Press.

Seuring S. and Muller M, (2008). From a literature review to a conceptual framework for sustainable supply chain management Journal of Cleaner Production 16 1699-1710 
Sgarbossa, F., \& Russo, I. (2016). A proactive model in sustainable food supply chain: Insight from a case study. International Journal of Production Economics.

Sigala, M. (2007). RFID applications for integrating and informationalizing the supply chain of foodservice operators: perspectives from Greek operators. Journal of Foodservice Business Research, 10(1), 7-29.

Smith, C.N., (2003). Corporate Social Responsibility: Whether or How?. California Management Review 45(4), 52-76.

Srivastava, S.K., 2007. Green supply-chain management: a state-of the-art literature review. International Journal of Management Reviews 9 (1), 53-80.

Tracey, M., Lim, J.S., Vonderembse, M.A., (2005). The impact of supply-chain management capabilities on business performance. Supply Chain Manag.: Int. J. 10 (3), 179191.

Turker, D. (2009). Measuring corporate social responsibility: A scale development study. Journal of business ethics, 85(4), 411-427.

Vachon, S and Klassen, R.D., (2008), "Environmental management and manufacturing performance: The role of collaboration in the supply chain", International Journal of Production Economics, Vol. 111, pp. 299-315.

Validi, S., Bhattacharya, A., \& Byrne, P. J. (2014). A case analysis of a sustainable food supply chain distribution system-A multi-objective approach. International Journal of Production Economics, 152, 71-87.

van der Vorst, J. G., Tromp, S. O., \& Zee, D. J. V. D. (2009). Simulation modelling for food supply chain redesign; integrated decision making on product quality, sustainability and logistics. International Journal of Production Research, 47(23), 6611-6631.

Vasileiou, K., Morris, J., (2006). The sustainability of the supply chain for fresh potatoes in Britain. Supply Chain Manag.: Int. J. 11 (4), 317-327

Walker H., Sistob L.D., McBainc D., (2008). Drivers and barriers to environmental supply chain management practices: Lessons from the public and private sectors. Journal of Purchasing \& Supply Management 14, 69-85. 
WCED (World Commission on Environment and Development). Our common future. Oxford: Oxford University Press; 1987.

Wetzels, M., Odekerken-Schröder, G., \& Van Oppen, C. (2009). Using PLS path modeling for assessing hierarchical construct models: Guidelines and empirical illustration. MIS quarterly, 177-195.

www.tuik.gov.tr/IcerikGetir.do?istab_id1/4153, accessed 16.04.2011.

Zaid, A. A., Jaaron, A. A., \& Bon, A. T. (2018). The impact of green human resource management and green supply chain management practices on sustainable performance: An empirical study. Journal of Cleaner Production, 204, 965-979. 


\section{-SURVEY FORM-}

Dear Participant

This survey is a part of scientific research which is organized by Professor Michael Bourlakis, Dr EmelAktas andMr Mehmet F.Acar from Brunel Business School, London. Your responses will be kept anonymous. Data collected from this survey is used only for academic research. Thank you for your participation.

Contact: emel.aktas@brunel.ac.uk

Please choose the appropriate response for the following questions.

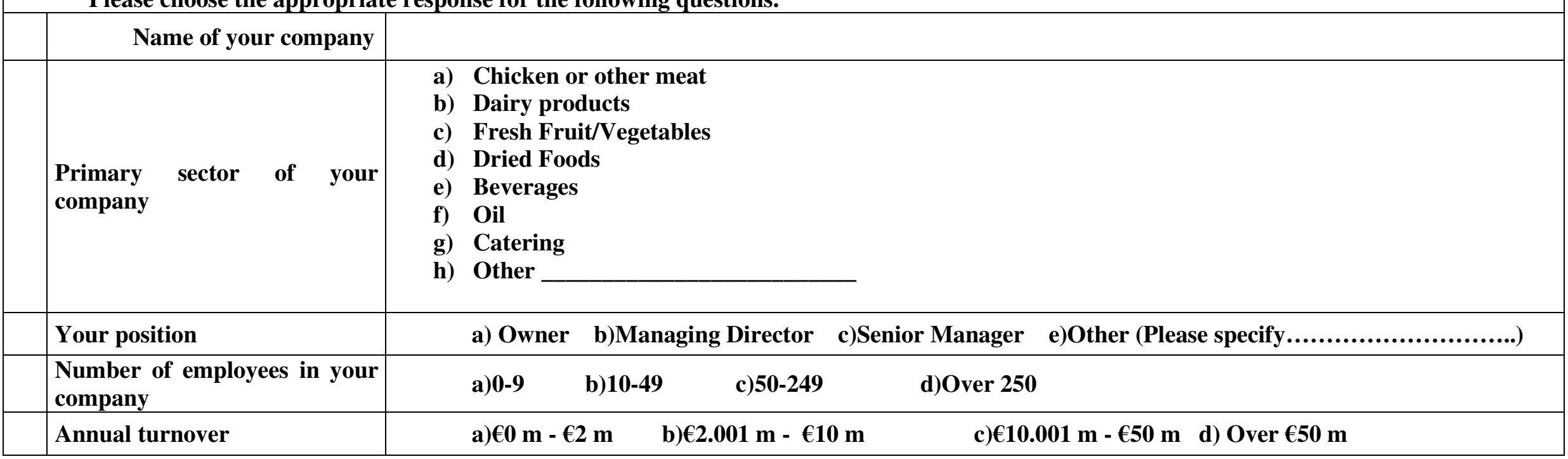

Please circle the option that represents your agreement with the sentences.

(1) Strongly Disagree; (2) Disagree; (3) Neither Agree/Nor Disagree; (4) Agree; (5) Strongly Agree

\section{Flexibility}

F1 $\quad$ We are flexible in extra product volume orders from retailers/wholesalers/caterers.

F2 We are flexible in delivering to extra points of sales for retailers/wholesalers/caterers.

F3 We are flexible in introducing new products to the market.

Please circle the option that best completes the sentences.

(1) Very Unsatisfactory; (2) Unsatisfactory; (3) About Right; (4) Satisfactory; (5) Very Satisfactory

Quality 


\begin{tabular}{|c|c|c|c|c|c|c|}
\hline Q1 & The quality of our products is & 1 & 2 & 3 & 4 & 5 \\
\hline Q2 & Shelf life of our products is & 1 & 2 & 3 & 4 & 5 \\
\hline Q3 & Our traceability system is & 1 & 2 & 3 & 4 & 5 \\
\hline Q4 & Our storage conditions are & 1 & 2 & 3 & 4 & 5 \\
\hline Q5 & Our delivery conditions are & 1 & 2 & 3 & 4 & 5 \\
\hline Q6 & Our quality of packaging is & 1 & 2 & 3 & 4 & 5 \\
\hline \multicolumn{7}{|c|}{$\begin{array}{l}\text { Please circle the option that represents your agreement with the sentences. } \\
\text { (1) Strongly Disagree; (2) Disagree; (3) Neither Agree/Nor Disagree; (4) Agree; (5) Strongly Agree }\end{array}$} \\
\hline \multicolumn{7}{|c|}{ Responsiveness } \\
\hline $\mathbf{R 1}$ & We are responsive in the pre-arranged delivery time as agreed with our customers. & 1 & 2 & 3 & 4 & 5 \\
\hline $\mathbf{R 2}$ & We are responsive in the delivery of the ordered type of product. & 1 & 2 & 3 & 4 & 5 \\
\hline $\mathbf{R 3}$ & We actively respond to retailers'/wholesalers'/caterers' complaints (call customers, send a sample of products, etc.) & 1 & 2 & 3 & 4 & 5 \\
\hline \multicolumn{7}{|c|}{$\begin{array}{l}\text { Please circle the option that represents your agreement with the sentences. } \\
\text { (1) Strongly Disagree; (2) Disagree; (3) Neither Agree/Nor Disagree; (4) Agree; (5) Strongly Agree }\end{array}$} \\
\hline \multicolumn{7}{|c|}{ Environmental Sustainability } \\
\hline E1 & We purchase environmentally friendly materials for our operations (recyclable and reusable packaging, containers, bags etc.) & 1 & 2 & 3 & 4 & 5 \\
\hline $\mathbf{E 2}$ & We ensure that our processes and products are environmentally sound. & 1 & 2 & 3 & 4 & 5 \\
\hline $\mathbf{E 3}$ & We try to minimize our energy consumption (electricity, fuel, gasoline etc.) & 1 & 2 & 3 & 4 & 5 \\
\hline E4 & We try to minimize our water consumption. & 1 & 2 & 3 & 4 & 5 \\
\hline \multicolumn{7}{|c|}{$\begin{array}{l}\text { Please circle the option that represents your agreement with the sentences. } \\
\text { (1) Strongly Disagree; (2) Disagree; (3) Neither Agree/Nor Disagree; (4) Agree; (5) Strongly Agree }\end{array}$} \\
\hline \multicolumn{7}{|c|}{ Social Sustainability } \\
\hline S1 & We work closely with our suppliers to develop their operations, accordingly. & 1 & 2 & 3 & 4 & 5 \\
\hline $\mathbf{S 2}$ & We encourage our suppliers to use resources optimally. & 1 & 2 & 3 & 4 & 5 \\
\hline S3 & We try to understand other chain members' interests. & 1 & 2 & 3 & 4 & 5 \\
\hline S4 & We source from environmentally sound suppliers. & 1 & 2 & 3 & 4 & 5 \\
\hline
\end{tabular}

